\title{
Physical Map Location of the Peptide Methionine Sulfoxide Reductase Gene on the Escherichia coli Chromosome
}

\author{
M. ATIQUR RAHMAN, $\dagger$ JACKOB MOSKOVITZ, JEFFREY STRASSMAN, \\ HERBERT WEISSBACH, AND NATHAN BROT* \\ Roche Institute of Molecular Biology, Roche Research Center, Nutley, New Jersey 07110
}

The enzyme peptide methionine sulfoxide reductase (MsrA), the product of the $m s r A$ gene, catalyzes the reduction of methionine sulfoxide residues in proteins to methionine $(1$, $3,4)$. During aerobic metabolism, methionine in proteins may be oxidized to methionine sulfoxide by biological reagents such as hydrogen peroxide, hydroxyl radicals, and hypochlorite and superoxide ions (reviewed in reference 2).

The Escherichia coli gene for MsrA has been cloned and sequenced (6). The position of this gene on the chromosome was determined by using a membrane which contains $\lambda$ phages bearing the entire $E$. coli genome on overlapping fragments (5). The membrane was probed with a 765-bp, ${ }^{32} \mathrm{P}-5^{\prime}$-endlabeled probe which contained the coding region of the $m s r A$ gene. Figure 1 shows that two positive clones were found that correspond to overlapping clones numbered 656 (5B5) and 657 $(\mathrm{E} 1 \mathrm{H} 3)$ on the Kohara map (5). These same clones were also
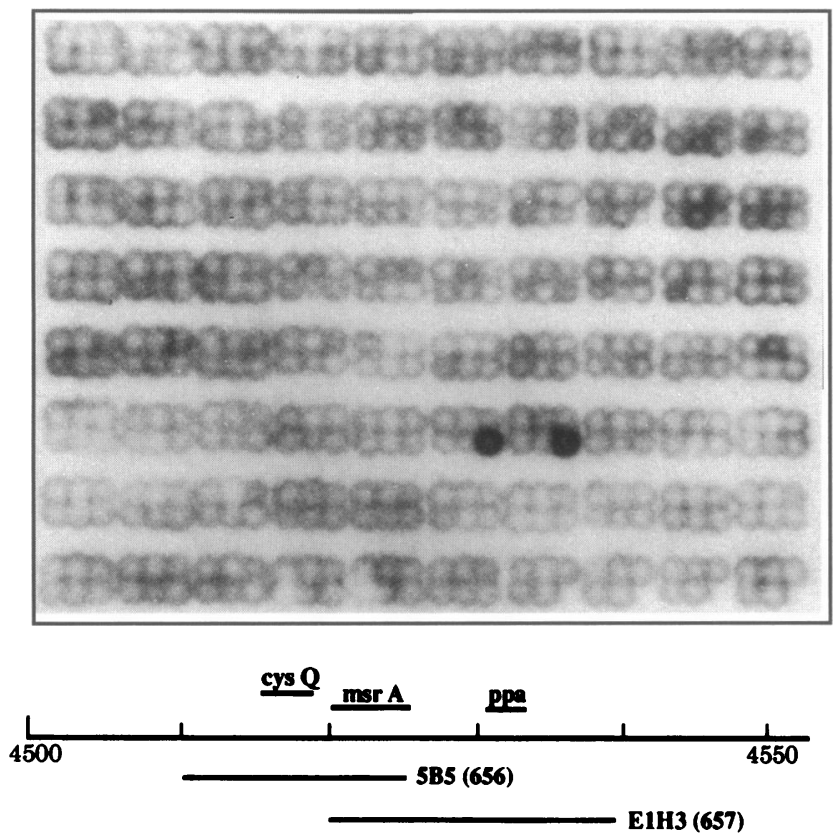

FIG. 1. Chromosomal mapping of the $m s r A$ gene. A ${ }^{32} \mathrm{P}$-labeled DNA probe complementary to the coding region of the $m s r A$ gene was hybridized to a membrane containing a phage library of the $E$. coli genome. The membrane was washed and exposed to X-ray film. Top, autoradiogram of membrane; bottom, portion of physical map of the genome showing the area of hybridization and alignment of phages 5B5 and E1H3.

* Corresponding author. Mailing address: Roche Institute of Molecular Biology, 340 Kingsland St., Nutley, NJ 07110. Phone: (201) 235-4746. Fax: (201) 235-5848.

$\dagger$ Present address: Department of Medicine, Yale University School of Medicine, New Haven, CT 06510. found to be positive when a 125-bp oligonucleotide covering the $5^{\prime}$ upstream region of the gene was used as a probe (data not shown). The overlap region is located approximately between 4520 and $4525 \mathrm{~kb}$ on the physical map and could easily accommodate the cloned 3-kb EcoRI fragment that contains the $m s r A$ gene. Restriction analysis using eight restriction endonucleases and sequence analysis defined the location of the gene even further, as shown in the physical map in Fig. 2. The restriction pattern corresponds to that reported by Kohara et al. (5) for this region of the $E$. coli chromosome. The $m s r A$ gene is transcribed in a counterclockwise direction at about $4523 \mathrm{~kb}$ on the physical map. This region lies between the cys $Q$ gene and the gene coding for a pyrophosphatase (ppa), which are found at about 95.6 and $95.9 \mathrm{~min}$, respectively, on the genetic linkage map (7). This would place the $m s r A$ gene at about 95.7 to $95.8 \mathrm{~min}$ on the genetic linkage map.

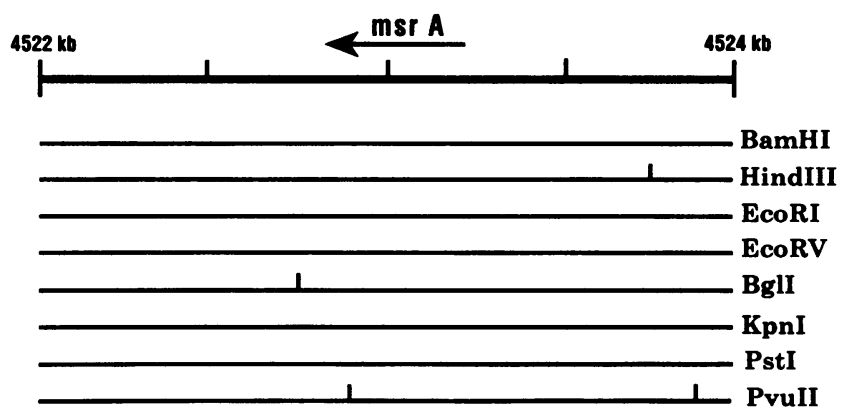

FIG. 2. Restriction map of the $m s r A$ region of the $E$. coli chromosome generated with eight restriction enzymes. The upper line gives the map units in chromosome kilobase pairs (5). The arrow indicates the position and transcriptional direction of the $m s r A$ gene.

\section{REFERENCES}

1. Abrams, W. R., G. Weinbaum, L. Weissbach, H. Weissbach, and N. Brot. 1981. Enzymatic reduction of oxidized $\alpha$-1-proteinase inhibitor restores biological activity. Proc. Natl. Acad. Sci. USA 78:74837486.

2. Brot, N., and H. Weissbach. 1988 . Methionine sulfoxide: chemistry and biochemistry, p. 851-872. In S. Patai and Z. Rappoport (ed.), The chemistry of sulphones and sulphoxides. John Wiley \& Sons, New York.

3. Brot, N., L. Weissbach, J. Werth, and H. Weissbach. 1981. Enzymatic reduction of protein-bound methionine sulfoxide. Proc. Natl. Acad. Sci. USA 78:2155-2158.

4. Fliss, H., G. Vasanthakumar, E. Schifiman, H. Weissbach, and N. Brot. 1982. Enzymatic reduction of oxidized chemotactic peptide $N$-formyl-L-methionyl-sulfoxide-L-leucyl-L-phenylalanine. Biochem. 
Biophys. Res. Commun. 109:194-201.

5. Kohara, Y., K. Akiyama, and K. Isono. 1987. The physical map of the whole $E$. coli chromosome: application of a new strategy for rapid analysis and sorting of a large genomic library. Cell 50:495508.

6. Rahman, M. A., H. Nelson, H. Weissbach, and N. Brot. 1992. Cloning, sequencing and expression of the Escherichia coli peptide methionine sulfoxide reductase gene. J. Biol. Chem. 267:1554915551.

7. Rudd, K. E. 1992. Alignment of E. coli DNA sequences to a revised, integrated genomic restriction map, p. 2.3-2.43. In J. Miller (ed.), A short course in bacterial genetics: a laboratory manual and handbook for Escherichia coli and related bacteria. Cold Spring Harbor Laboratory Press, Cold Spring Harbor, N.Y. 